\title{
Does Financial Flexibility foster Investment Efficiency? Evidence from an Emerging Market
}

\author{
Md. Rashidul Islam ${ }^{1}$, Monirul Alam Hossain ${ }^{2 *}$, Mohammad Shamsu Uddin ${ }^{3}$, Dawit Teclemariam Bahta ${ }^{4}$ \\ ${ }^{1}$ School of Accounting, Dongbei University of Finance and Economics, Liaoning Province, Dalian, CHINA \\ 2Professor and Chairperson, Department of Business Administration, Bangladesh University, Dhaka, BANGLADESH \\ ${ }^{3}$ School of Economics and Management, Dalian University of Technology, Dalian 116024, CHINA \\ ${ }^{4}$ School of Business Administration, Dongbei University of Finance and Economics, Liaoning Province, Dalian, CHINA \\ *E-mail for correspondence: monirulhossain@gmail.com
}

https://doi.org/10.18034/abr.v10i2.476

\begin{abstract}
This research aims to examine the relationship between financial flexibility and investment efficiency empirically, i.e., how financial flexibility effects suboptimal investments and efficiency. To attain the research objectives, we used panel data for 18 years (2000-2017) obtained from the CSMAR database; and also used the GMM estimation technique for research outcome. Our empirical results reveal that financial flexible firms can reduce the suboptimal investment by increasing investments compared to the inflexible firms and increases the investment efficiency. Also, financially flexible firms generate additional power to borrow external finance by showing a significant positive relationship with current and expected leverage. This research considers China as an emerging economy that is in the transition of being a developed country with a unique set of corporate governance, which ensures the independence of independent directors by providing authority to disclose important board decisions to the public. Besides, the governance system is highly monitored by the government, which in turn reduces and information asymmetry and enact to provide investment efficiency. Thus, the outcome of this research offers several conceptions for researchers and managers, which may be useful for both emerging and advanced countries. The results indicate that financial flexibilities lead to excess debt capacity, and this capacity can be used in the bad time when external financing is challenging to fund profitable projects, and also financial flexibility can be used to exploit lucrative projects and reduce the underinvestment or overinvestment entailing investment effectiveness. Previous research addresses the issue related to cost and benefit, information asymmetry, ownership concentration, and firms' propensity to financial flexibility. A little research conducted on financial flexibility and investment efficiency in the developed market (in Europe and USA), and thus the issue of and financial flexibility measured in unused debt capacity and investment efficiency, is one of the fundamental research in the emerging economy.
\end{abstract}

Key words: Financial Flexibility, Investment Efficiency, Emerging Economy

\section{INTRODUCTION}

Financial flexibility is the firm's capability to raise economic resources to respond to expected investment and expansion opportunities as well as provide strength to face any future unexpected events and contributes to maximizing firm's value (Cherkasova and Kuzmin, 2018; Ma and Jin, 2016; Denis and McKeon, 2009; Byoun, 2007; Bates et al., 2009). It is also dubbed as a strategic tool which enables firm's to avoid financial distress and instigates investment in the positive net present value projects
(Bonaimé et al., 2013; Ma and Jin, 2016; Bolton et al., 2019), and financial flexible firms enjoy more comfortable access to capital markets and raise funds at lower costs to fund new growth opportunities even if in the crisis (ArslanAyaydin et al., 2014; Oded, 2019).

The agency theory describes the agency costs involved in the executive's benefits at the cost of owners' (Jensen and Meckling, 1976). The executives who are in control of corporate affairs may not pursue activities for the principal benefits, which in turn involve a cost of 
monitoring, bonding costs as well as a residual loss (Jensen, 1994). When the information asymmetry is high, executives can pursue an interest in hurting the owners. Moreover, agency theory predicts that when a business has excess money, managers can invest it in bad projects or squander it (Jensen, 1986). Thus, agency issues affect financial flexibility due to the higher information asymmetry and lower corporate governance monitoring role in the emerging economy. Under this situation, it is a big question, "Does Financial Flexibility foster Investment Efficiency in the Emerging Economy?

Emerging countries' are the countries whose stock market has gone through a radical reformation and introduction of corporate governance guidelines as well as setting regulatory bodies and regulations. For example, China went through radical reform of board independence in 2001, and stock restructured in 2005 ( $\mathrm{Li}$ et al., 2015) and corporate governance guidelines in 2006. Emerging economies also consist of unsophisticated and less developed financial markets as well as inefficient capital markets where commercial banks play a pivotal role in financing (Al-Najjar and Clark, 2017). Besides, economies are characterized by high information asymmetries, the prevalence of more fabulous family and ownership concentration; less developed legal markets as well as political and economic instability. Under this situation, to explore the relationship between financial flexibility and investment efficiency becomes essential, and this research is motivated to address the crucial issue in the emerging economy.

According to different theories and prior empirical research evidenced the mitigation of suboptimal investments primarily influenced by financial flexibility (Cherkasova and Kuzmin, 2018). The effects of firms' financial flexibility and performance mostly studied in the late 2000s. One of the significant works conducted by Byoun (2007) and DeAngelo and DeAngelo (2007) focused on the determination of sources of financial flexibility. However, the recent works on this area focused on the implication of financial flexibility and gained a more holistic view of its computation. The association between financial flexibility and investment activities linked with the pecking order theory of Myers and Majluf (1984), and also covered by Yung et al. (2015), Ferrando et al. (2017) and others. However, Ma and Jin (2016) and Nouri and Jafari (2016) provides brief considerations of financial flexibility and its impact on investment efficiency.

The relevance and practicality of financial flexibility and investment efficiency attracts researchers and scholars. This research contributes to the existing literature by evaluating the impact of financial flexibility, in the form of unused debt capacity on the decline of suboptimal investment choice (by cutting the level of over and underinvestment) compared to inflexible firms. At the same time, scholars are more focused on how financial flexibility affects the level of investments, equity payout, and the firm's value.
The practical value of this research is managers can use financial flexibility for investment policy preparation, which is, in turn, increases the firms' value. Unlike prior research, this research has united two types of decision financial and investment. The study reveals that the perfect selection of capital structure leads to optimal investment decisions by reducing the suboptimal investment and positively contributes to the firm's value.

The investment efficacy during the financial crisis (20082009) raises many questions on investment strategies by the firm's sizes. To investigate these effects, this research considers China as a large and rapidly growing economy in the emerging economy. This study assumes that it is easier to implement an optimal investment strategy for flexible financial firms during the recessionary period due to the availability of surplus resources. Also, this research explores firms of multiple sizes, considering that larger firms have more freedom and are less risky. Consequently, these firms can implement more effective investment decisions.

Our contribution to the literature on financial flexibility (unused debt capacity) and investment efficiency is threefold. First, using the 18425 observation of emerging Chinese Market data, we extend the previous research on financial flexibility and investment efficiency in the context of emerging markets. Second, we explore how financial flexibility reduces suboptimal investments; finally, how financial flexibility is associated with investment efficiency. Our paper constructed as follows. In the next section, we present the literature review and developed out principal research hypotheses. In part 3, we discuss the sample and methodology employed to conduct the research. We then proceed to section four to analyze the empirical results, and finally, we put concluding remarks and implications of the study.

\section{LITERATURE REVIEW AND HYPOTHESIS DEVELOPMENT}

\section{Investment Activity and Efficiency}

The worthiness of financial flexibility is closely associated with firms' investment ability. In the imperfect markets, financial flexibility in the form of conservative leverage policy instigates managers to make a decision (those that are contracting issues and asymmetric information).To avoid possible financial distress and economic shocks, firms' are eager to preserve a certain level of flexibility to invest in lucrative projects in the possibilities that arise.

The investment efficiency is associated with deviations from the optimal level of investments. It implies that the optimal level of investments is the level of investments at which the firms opt-out to pursue profitable projects and reject the projects which will generate negative earnings (Cherkasova and Kuzmin, 2018). In the economy where firms face imperfect capital markets, they usually suffer 
from the agency as well as asymmetric information problems, which may insist companies choose projects with negative Net Present Value (NPV), and not to continue the projects with positive NPV. According to Cherkasova and Kuzmin (2018), those situations are usually termed as over investment or underinvestment, respectively. However, why firms preserve their low debt ratio, even when there are profitable options to gain external funds is explained by La Rocca et al. (2008). They demonstrate that for individual period firms maintain a specific leverage ratio due to their strategic tools as well as their market competitions (La Rocca et al., 2008).

How to calculate investment efficiency is demonstrated by Titman et al. (2009). The most recent work Cherkasova and Zakharova (2016), also shows the approaches to determine investment efficiency. They used the average historical investments for five or three year's periods to calculate the level of optimal investments. If the current period's investment volume and last three years' average investment volume is the same, then the firm is undertaking the optimal investment strategy (Cherkasova and Zakharova, 2016). However, Richardson (2006) construe the total investments as the sum of total expenditure, acquisitions, and research and development expenditure. The total investment can be segregated as maintenance investments, investment expenditure into efficient projects, and abnormal investments.

To examine investment efficiency Richardson's model proves to be more appropriate. This model also followed by Han and Zhang (2016) and modified the model to pursue their research objectives. The revised model includes monetary policy factors, i.e., growth rates, money supply, and changes of policy to measure investment efficiency.

\section{Connecting Financial Flexibility and Investment Efficiency}

Financial flexibility is determined by the leverage, internal funds, or cash holding, which becomes increasingly important for firms' investment purposes. The link of leverage, internal funds, and cash holding with investment efficiency has created a new area of study being introduced by financial researchers. Current studies expand the term financial flexibility as the missing link between the decision of capital structure and firm performance (Cherkasova and Kuzmin, 2018). Scholars prescribe financial flexibility as a mediator between external financing power and the execution of positive NPV projects on time and in line with the competition.

The behavioral terms can explain the effect of financial flexibility. The financial flexibility allows managers to invest in riskier projects despite prevailing market friction, which eventually invests funds in negative NPV or loss projects. Financial flexibility also minimizes shareholder's agent conflicts (Estwick, 2016; Islam, 2019). A large amount of debt and investors' confidence is negatively affected due to the outcome of debt could end up with the risk of default or bankruptcy of the firm. However, the rational behavior of the managers with investments could minimize the suspicious of investors and eliminate inefficient investments to a great extent (Myers, 1974).

Financial flexibility is one of the essential parts of capital structure decisions, which have a significant association with firms' future investments (De Jong et al., 2012). The authors further state that the firms' capability to raise external finance results in the lessening of investment distortions, particularly in constrained financing. The work of De Jong et al. (2012) implies that financial flexibility is the prominent reason to keep lower leverage, even if the firms' have the opportunity to raise finance with a lucrative option for tax savings.

Financial flexible firms are less affected by the financial crisis (Arslan-Ayaydin et al., 2014; Mittoo and Bancel, 2011), and European firms affirm that during the downfall market, flexibility is the essential determinant of capital structure policy. The recent study conducted by Ma and Jin (2016) introduced a mechanism of investment scale and efficiency that acts as a mediator between financial flexibility and firm performance, which shows that a positive association between financial flexibility and investment strategy-scale and efficiency. However, Nouri and Jafari (2016) state that financial flexibility can lead to both over or underinvestment; thus, it is essential to study financial flexibility and investment efficiency. To achieve the research goal, this study wants to unify the methods for determining financial flexibility and investment efficiency to examine the relationship between them. Also, the given theoretical background offers the opportunity to evidence that firms can utilize flexibility factors in their investment policies for making effective financial decisions.

\section{Financial Flexibility and Investment Expenditure}

Firms inclined to avoid the abnormal amount of debt despite the tax advantage of getting debts to be financially flexible (Modigliani and Miller, 1963). Also, firms with minimum leverage policy assist them in becoming financially flexible, which strengthens their investment ability (Marchica and Mura, 2010). Financial flexibility provides an opportunity for managers to enhance investment in capital expenditures. These imply that financial flexibility restrained firms away from borrowing and create an opportunity for future growth. The principal objectives this research is to define the association between financial flexibility and investment efficiency and this approach is reflected in the hypothesis

\section{$H_{1}$ : Financial flexible firms are positively associated with future investment expenditure}

Firms use financial flexibility to respond to the positive investment opportunities and adapt their investment strategy Ma and Jin (2016); Denis and McKeon (2012). They show that a firm's financial flexibility and firm 
performance are positively associated while serving investment strategy-scale and efficiency, which implies that financial flexibility provides the opportunity to the managers not only to enhance the level of investments but also to employ the funds in a project where the profitability would be higher, and risk would be lower, and escape the plans where the amount of risk is higher and return is more economical. Consequently indicates that financial flexibility can lead to better investment strategy and the firm's performance.

$\mathrm{H}_{2}$ : Financial flexibility can reduce the level of suboptimal investments

\section{Economic Crisis and Investment Efficiency}

This study proposes several additional hypotheses involving additional factors to get more insight into the financial flexibility and investment efficiency, i.e., company size and economic crisis. This is due to the reason that small firms and large firms' financial characteristics are different, and small firms used to be more financially flexible, holding more cash than large firms. Financial flexibility and firms' performance significantly affected during the crisis. Arslan-Ayaydin et al. (2014), evidence that firms with conservative leverage policy and had financial flexibility in the form of cash holdings created a buffer during the crisis.

\section{$H_{3}$ : Financial Flexibility and investment efficiency is positively related in economic crisis}

Credit organizations evaluate financial flexibility and offer credits to flexible firms at lower and little risks Byoun (2007). The status of financial flexibility can provide signals on the large or small firms' financial health and suggest competitive advance of issuing finance to the firms who are seeking funds for their development projects. The existence of financial flexibility is more common in big firms; it also plays a crucial role in the policies of smaller firms'(Ferrando et al., 2017). Big flexible firms allow managers to have an effective investment policy, whereas a small firm's flexibility provides multiple credit options to fund their investments.

H4: Financial flexibility has an identical impact regardless of firms' size

\section{METHODOLOGY FOR FINANCIAL FLEXIBILITY AND INVESTMENT EFFICIENCY}

\section{Sample and Data}

The Sample of our data set consists of nine different industry where machinery and equipment is the largest industry occupying 848 firms' $(41.69 \%)$ of our dataset followed by petroleum (18.34\%), metal $(12.93 \%)$ \& nonmetal, medicine $(11.21 \%)$, textile paper \& printing $(4.33 \%)$ and others (see figure 1$)$.

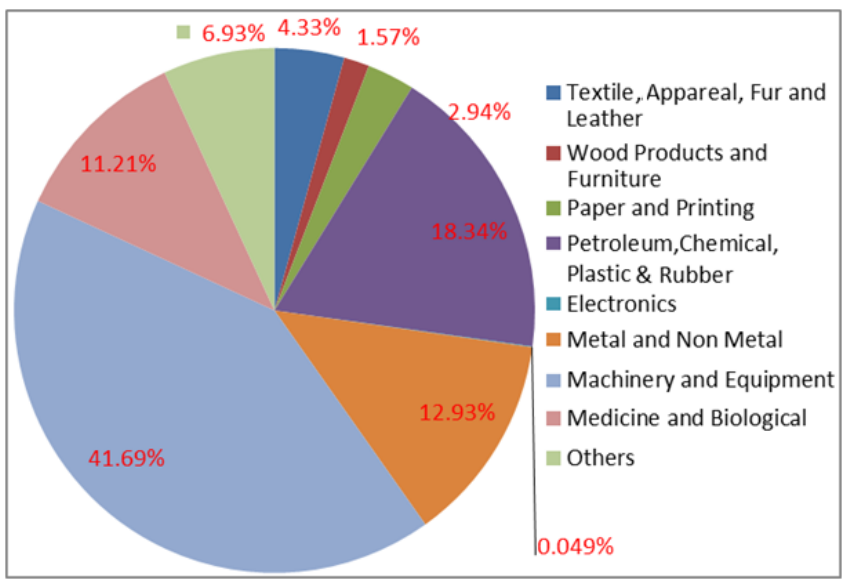

Figure 1: Industry Classification in our data sample

To examine the relationship between financial flexibility and investment efficiency, we obtained panel data of 2034 manufacturing companies 18 years (2000-2017) data composed of 18425 firm year's observation from the CSMAR database (see Table 1 for sample details). Due to the missing data, we proceed with unbalanced data. This database contains details data of Chinese listed and unlisted A, B, H, and N categories companies. In China, not all shares are tradable in the Stock Exchanges. A type of shares are classified as domestic and tradable in the open market and mostly held by individuals.

Table 1: Sample details and their construction

\begin{tabular}{|l|c|c|c|}
\hline Variable & $\begin{array}{c}\text { No of } \\
\text { Firms }\end{array}$ & Observation & Lost \\
\hline Year & 2034 & 18,425 & 0 \\
\hline Total Assets & & 18,085 & 380 \\
\hline Unused Debt Capacity(UDC) & & 18,105 & 320 \\
\hline Leverage & & 18,084 & 341 \\
\hline Return on Assets & & 18,084 & 341 \\
\hline Cash & & 18,084 & 341 \\
\hline Firm Sizeln (FS) & & 18,084 & 341 \\
\hline Tangibility (TAN) & & 18,084 & 341 \\
\hline Investment (INV) & & 18,084 & 341 \\
\hline Cash Flow (CFLOW) & & 18,084 & 341 \\
\hline Operating Profit & & 18,085 & 340 \\
\hline Market to Book (MTB) & & 16,694 & 1731 \\
\hline Lag Investment (INVt-1) & & 18,084 & 341 \\
\hline Lag Leverage (LEV t-1) & & 18,084 & 341 \\
\hline Lag Return on Investment (ROA t-1) & & 18,084 & 341 \\
\hline Lag Unused Debt Capacity (UDC $\mathrm{t}-1)$ & & 18,104 & 321 \\
\hline Lag Firm Size (FS $\mathrm{t}-1)$ & & 18,084 & 341 \\
\hline Lag Market to Book Ratio (MTB $\mathrm{t}-1)$ & & 16,694 & 1731 \\
\hline Lag Tangibility (TAN $\mathrm{t}-1)$ & & 18,084 & 341 \\
\hline lagCash (Cash t-1) & & 18,084 & 341 \\
\hline Lag Cashflow (CFLOW $\mathrm{t}-1)$ & & 18,084 & 341 \\
\hline Crisis & & 18,425 & 0 \\
\hline Residuals & & 16,528 & 1897 \\
\hline Small or Big firms & 18,085 & 340 \\
\hline
\end{tabular}

On the other hand, type $\mathrm{B}, \mathrm{H}$, and $\mathrm{N}$ shares are classified as foreign share based on holders residency ( $\mathrm{Xu}$ and Wang, 1999). We excluded banks and other financial institutions as 
these firms are regulated and managed by their respected regulatory agencies as well. However, for our research purposes, we downloaded and matched only A-type manufacturing companies' shares as they are identical in feature and reasonable to produce the best research outcome.

\section{Variables and their calculations}

Table 2 shows the details of the dependent, independent, and control variables used in this research.

Table 2: Description of Variables Used in the Research

\begin{tabular}{|c|c|c|}
\hline Name of Variables & Acronyms & Description \\
\hline Investment Efficiency & IE & Absolute value of residuals derived from investment models (Richardson, 2006). \\
\hline Financial Flexibility & FF & $\begin{array}{l}\text { Unused debt capacity, it is the borrowing capacity which is unused } \\
\text { UDC=(TDC-LEV) suggested by (Estwick, 2016). }\end{array}$ \\
\hline Total Debt & TDC & TDC is the weighted of assets tangibility \\
\hline Capacity & & $\begin{array}{l}0.715^{*} \text { receivables }+.547^{*} \text { inventory }+.535^{*} \mathrm{PPE} \text { divided by total assets following } \\
\text { related literature (Almeida and Campello, 2007;Almeida et al., 2014). }\end{array}$ \\
\hline Leverage & LEV & Book value of total debts divided by total assets \\
\hline Market to Book & MTB & $\begin{array}{l}\text { It is calculated as (Book Value of Total Assets-Book Value of Equity +Market } \\
\text { Value of Equity) scaled by total assets. }\end{array}$ \\
\hline Firm Size & FS & Natural Logarithm of total assets \\
\hline Cash Flow & CFLOW & Net operating income plus depreciation and amortization scaled by total assets \\
\hline Return on Assets & ROA & Net operating income divided by total assets \\
\hline Asset Tangibility & TAN & Total fixed assets divided by total assets \\
\hline Investment & INV & $\begin{array}{l}\text { The ratio of the net changes in property, plant, and equipment with the addition } \\
\text { of the maintenance costs to the total assets }\end{array}$ \\
\hline Cash & Cash & Cash and cash equivalents divided by total assets \\
\hline Crisis & Crisis & Dummy variable if a year is $2008=1$ otherwise 0 \\
\hline Firm Size & Size & $\begin{array}{l}\text { Dummy variable if the total assets }>=\text { average total assets, otherwise }=0,1 \text { is for } \\
\text { large firms and } 0 \text { is for small firms }\end{array}$ \\
\hline Financial Flexibility & FF & Dummy variable if $U D C>=0$ then 1 otherwise 0 \\
\hline
\end{tabular}

\section{Dependent Variables: Investment Efficiency}

Investment efficiency is the point where firms have no underinvestment or overinvestment. It is the choice of the firm that motivates to pursue profitable projects and rejects all loss-making projects. Investment efficiency is widely related to the free cash flows of the firms as well as the investment decision of the firms. Under the agency cost prediction, in the emerging markets, information asymmetry is usually high. When managers have the free positive cash flow, they can squander it or invest in a project that may generate a loss. And also, managers can squander firms cash when they have access to cheap cost funds (Cherkasova and Kuzmin, 2018; Richardson, 2006).

The investments over the optimum level of investments are dubbed as overinvestment or abnormal investments, while investments below the optimum level, we recognize them as under investments. We measure investment efficiency based on the optimal investment approach, where we follow two steps: first, we estimate the investments and get the residual from the results, and Second, we consider the absolute value of residual as investment efficiency (Richardson, 2006). The positive residuals are recognized as overinvestments, while negative residuals are regarded as under investments (e.g., Cherkasova and Kuzmin, 2018).
Independent Variable: Financial Flexibility

In recent literature, Arslan-Ayaydin et al. (2014), financial flexibility is a proxy of a firm's leverage and cash holdings. They suggest that firms with high cash holding and low leverage are flexible firms as these firms as a more exceptional ability to raise external funds. Conversely, firms with high leverage and weak cash position indicate less flexible firms. Consistent with this approach, Ma and Jin (2016) measure financial flexibility considered firms liquidity, leverage, and internal funds. Also, for calculating financial flexibility, the researches utilize Unused Leverage Capacity (ULC) measured by the leverage prediction model, and scholars use three consecutive year ULC as financial flexibility.

However, critics criticize the three-year consecutive ULC approach to measure financial flexibility is unpractical due to its non-representativeness of the firm's present economic condition (Estwick, 2016; Cherkasova and Kuzmin, 2018). Thus, we use an approach of weighted assets tangibility that represents the firm's real debt financing capacity (UDC) as a proxy of financial flexibility by including weighted receivables, inventory and property, plant, and equipment that initially suggested by (Almeida and Campello, 2007). We calculate Unused Debt Capacity (UDC) following in two steps: First, computing 
$\mathrm{DC}$ as $0.715^{*}$ receivables $+.547^{*}$ inventory $+.535^{*} \mathrm{PPE}$ divided by total assets following related literature (Almeida and Campello, 2007; Almeida et al., 2014). We then deduct the leverage ratio from Total Debt Capacity (TDC) to get Unused Debt Capacity (UDC). Financial flexibility is then assigned one if positive debt capacity and 0 for negative debt capacity.

\section{Endogeneity and Causality Issues}

This research proceeds with the Generalized Methods of Moments (GMM) method to explore the relationship between financial flexibility and investment efficiency due to the potential endogeneity issues lay in the econometric model. The endogeneity issues have been addressed in this study in two ways. First, this research employs a fixed-effect model in the analysis that can relatively disregard the endogeneity issue caused by missing variable bias (Wooldridge, 2009). Secondly, this study also employs a more robust system, Generalized Methods of Moments (GMM) model following Blundell \& Bond (1998). The system GMM, by default, creates the instrumental variables to remove the endogeneity issue. We also control industry and year fixed effect using the fixed-effect model, as well as consider one year lag of dependent variable to manage the endogeneity.

\section{Empirical Models}

The net effects of the dependent and independent variable to gauge, this research approach the Generalized Methods of Moments (GMM) model due to its effectiveness of removing time-invariant features of firms'. Therefore we propose the model as:

$\mathrm{Y}_{\mathrm{it}}=\beta_{1} X_{\mathrm{it}}+\alpha_{\mathrm{i}}+\delta_{\mathrm{i}}+\eta_{\mathrm{t}}+u_{\mathrm{it}}$

Where,

$\alpha_{\mathrm{i}(i=1 \ldots n)}$ is the unknown intercept for each entity ( $n$ entityspecific intercepts). $Y_{\text {it }}$ is the outcome variable, where $i=$ entity and $t=$ time. $X_{\mathrm{it}}$ represents one predicting variable; $\beta_{1}$ is the coefficient for that predicting variable. $\delta_{i}$ is the industry fixed effects, and $\eta_{t}$ is the year fixed effects. $u_{i t}$ is the error term.

\section{Defining Financially Flexible Firms'}

Following the model of Marchica and Mura (2010) and extended by Cherkasova and Kuzmin (2018), this research uses the unused debt capacity as the proxy of financial flexibility. According to Graham and Harvey (2001) and Mittoo and Bancel (2011), firms' financial flexibility is initially preserved by debt policy. They argued that firms maintained financial flexibility considering firms' future growth opportunities and developed a model that estimates the observed and predicted leverage of the firms. To estimate the firms' leverage, this study uses the modified Marchica and Mura (2010) model as follows:

$\operatorname{LeV}_{i, t}=\beta_{0}+\beta_{1} \mathrm{LEV}_{\mathrm{i}, \mathrm{t}-1}+\beta_{2} \mathrm{MTB}_{\mathrm{i}, \mathrm{t}}+\beta_{3} \mathrm{FS}_{\mathrm{i}, \mathrm{t}}+\beta_{4} \mathrm{TAN}_{\mathrm{i}, \mathrm{t}}+$

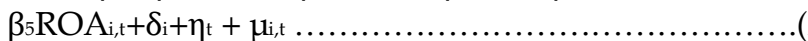

Where,

$\mathrm{Lev}_{\mathrm{i}, \mathrm{t}}$ is the leverage ratio calculated using the book value of total debts scaled by total assets. MTB is the Market to Book Ratio determined using the formula of the book value of assets market value of equity-book value of equity divided by the book value of total assets. FS is the firm size that represents the natural logarithm of total assets. TAN is the tangibility that is calculated by using total fixed assets divided by total assets. ROA is the return on assets calculated by using net operating income divided by total assets, $\boldsymbol{\delta}_{\mathrm{i}}$ is the industry fixed effects, and $\boldsymbol{\eta}_{\mathrm{t}}$ is the year fixed effects. $\boldsymbol{\mu}_{\mathrm{i}}$ is the error term.

Following the proposed model of Arellano and Bond (1991) using the generalized methods of Moments (GMM), this study predicts the estimated leverage. The benefits of using this model are it allows the researcher to control co-linearity as well as heteroscedasticity issues arising from applying the lagged value of the predicted variable (Cherkasova and Kuzmin, 2018). It is considered that firms with a negative change actual leverage in the predicted leverage persists Unused Debt Capacity (UDC), meaning firms can utilize additional debt financing.

The association between Financial Flexibility and Investment Ability

Following Richardson (2006), this research computes the total investment as the summation of new investments and the maintenance costs to find the level of investments of each firm. We expect that financial flexible firms and investment should be significantly positively associated. To test the hypothesis $H_{1}$ : Financial flexible firms are positively associated with investment expenditure; this study uses the following empirical model:

$\operatorname{Inv}_{i, t}=\beta_{0}+\beta_{1} \operatorname{INV}_{i, t-1}+\beta_{2} \mathrm{CFLOW}_{i, t}+\beta_{3} \mathrm{ROA}_{i, t}+\beta_{4} \mathrm{FF}_{\mathrm{i}, t}+\beta_{5}\left(\mathrm{FF}_{\mathrm{i}, \mathrm{t}}\right.$

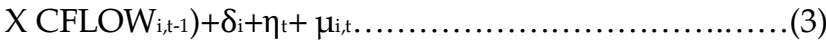

Where,

Invi,t is the investment represented the changes of property, plant, and equipment plus capital assets maintenance costs scaled by the total assets. $\mathrm{INV}_{\mathrm{t}-1}$ is the following year investments; $\mathrm{CFlOW}$ is the cash flows computed using net operating income before interest and taxes plus depreciation and amortization divided by total assets. ROA is the return on assets calculated using net operating income divided by total assets. FF is the financial flexibility proxy of unused debt capacity, $\boldsymbol{\delta}_{\mathrm{i}}$ is the industry fixed effects, and $\eta_{t}$ is the year fixed effects. $\mu_{i, t}$ is the error term.

According to Marchica and Mura (2010), financial flexible firms have a negative relationship to the cash flows, which indicates that financial flexible firms invest in new projects form leverage and reluctant to use their internal funds. This research uses model (3) for investment in testing the uses of leverage to fund investment. 


\section{Financial Flexibility and Investment Efficiency}

The investment efficiency is measured by the level of overinvestment and underinvestment following Richardson (2006) model, which also referred to as abnormal investments. The empirical model predicts the investment level based on explanatory and control variables. This research adopted the basic model with additional explanatory and a control variable that affects firms' investment level. The proposed model is:

$\operatorname{Inv}_{\mathrm{i}, t}=\beta_{0}+\beta_{1} \mathrm{LEV}_{\mathrm{i}, \mathrm{t}-1}+\beta_{2} \operatorname{Cash}_{\mathrm{i},-1-1}+\beta_{3} \mathrm{ROA}_{\mathrm{i}, \mathrm{t}-1}+\beta_{4} \mathrm{MTB}_{\mathrm{i}, t-}$

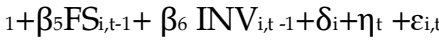

Where,

Inv is the investment of firm $i^{\text {th }}$ in time of $t . \mathrm{LEV}_{\mathrm{i}, t-1}$, is the following year's leverage ratio. Cash $\mathrm{h}_{\mathrm{i}, \mathrm{t}-\mathrm{i}}$ is the ratio of cash and cash equivalent divided by total assets. $\mathrm{ROA}_{\mathrm{i}, \mathrm{t}-\mathrm{i}}$ is the lagged return on assets. MTB $i, t-1$ is the lagged market to book ratio. $F S_{i, t-1}$ is the following year firm size. $I N V_{i, t-1}$ is the lagged investment. $\boldsymbol{\delta}_{\mathrm{i}}$ is the industry fixed effects, and $\eta_{t}$ is the year fixed effects, and $\varepsilon_{i, t}$ is the error term.

From equation four, we will compute the observed and residual of investments. The residual will be used as a dependent variable as a proxy of investment efficiency (Cherkasova and Kuzmin, 2018; Richardson, 2006). The positive value of residual will indicate overinvestment and negative value of residual represent underinvestment. To estimate the investment efficiency, this research proposes the following empirical model

$\mathrm{IE}_{\mathrm{i}, \mathrm{t}}=\beta_{0}+\beta_{1} \mathrm{FF}_{\mathrm{i}, \mathrm{t}}+\beta_{2} \mathrm{FS}_{\mathrm{i}, \mathrm{t}-1}+\beta_{3} \mathrm{TAN}_{\mathrm{i}, \mathrm{t}-1}+\beta_{4} \mathrm{ROA}_{\mathrm{i}, \mathrm{t}-1}+\delta_{\mathrm{i}}+\eta_{\mathrm{t}}+\mu_{\mathrm{i}, \mathrm{t}}$

Where,

IE is the investment efficiency measured by the residuals of equation three (3).FF is the financial flexibility measured by the firms' unused debt capacity; $\mathrm{FS}_{\mathrm{i}, t-1}$ is the lagged firm size; TAN ${ }_{i, t}-1$ is the lagged asset tangibility; $R A_{i, t-1}$ is the lagged return on assets. $\delta_{i}$ is the industry fixed effects, and $\eta_{t}$ is the year fixed effects, and $\mu_{i, t}$ is the error term.

For further analysis of investment efficiency, this study splits firms as large and small. Also, we would like to look at the investment efficiency according to the firm's size.
This research identifies small firms are those whose average assets are less than the mean total assets of the firms'. We then generate dummy variables as if the firm falls into the small firm's category; we assigned 0 , and if it falls within the large firms, then 1 . The same approach also applied by Cherkasova and Kuzmin (2018).

Following Cherkasova and Kuzmin (2018), we extend the equation (4) by accommodating the world financial crisis, although China had not been severely affected by the world economic crisis. This research considers 2008 as a crisis year as the crisis began in 2007 and its effect on financial statement reported in 2008. We then assigned dummy variables for crisis year (2008) $=1$ and 0 otherwise.

\section{RESULTS AND DISCUSSION}

\section{Descriptive Analysis}

Table 2 summarizes the basic descriptive statistics for the key variables of this research from 2000 to 2017. The table shows that the average unused debt capacity -0.834 , which indicates that about $83 \%$ of the firms have no unused debt capacity. It implies that $17 \%$ of companies are financially flexible. However, an actual number of flexible firms may be higher as the range of unused date capacity is -752.97 to 0.62 . The average leverage to total assets is 1.15 times the firms' total assets, and return on assets is $4 \%$.

The firm holds 18.\% of their asset as liquid assets and 26.\% as property, plant, and equipment. The average growth of investment is $21 . \%$ to total assets, and the cash flow ratio is $4 \%$ of total assets. The growth a rate is measured by MTB is $85 \%$ of total assets.

\section{Multicollinearity}

We examine multi co-linearity between the explanatory variables through the Pearson Pairwise correlation matrix presented in Table 3. The results allow the researcher to exclude the likely existence of multi co-linearity between variables in the prescribed empirical model. The highest value is 0.743 between MTB and Lag MTB. However, the value below 0.90 is considered harmless, according to Hasan et al. (2014); Bryman and Cramer (1997). The results of the correlation matrix suggest that multi co-linearity is not a problematic issue to analyze multivariate analysis. 
Table 2: Descriptive statistics of all variables

\begin{tabular}{|c|c|c|c|c|c|}
\hline Variable & Obs & Mean & Std. Dev. & Min & $\operatorname{Max}$ \\
\hline Year & 18,425 & 2010 & 5 & 2000 & 2017 \\
\hline Total Assets & 18,085 & 6170000000 & 18100000000 & 0 & 724000000000 \\
\hline Unused Debt Capacity (UDC) & 18,105 & -0.83 & 11.31 & -752.97 & 0.62 \\
\hline Leverage (LEV) & 18,084 & 1.15 & 11.32 & 0.00 & 753.23 \\
\hline Return on Assets (ROA) & 18,084 & 0.04 & 0.14 & -6.65 & 1.47 \\
\hline Cash Ratio & 18,084 & 0.18 & 0.14 & 0.00 & 1.00 \\
\hline Firm Size $\ln (\mathrm{FS})$ & 18,084 & 9.39 & 0.51 & 7.03 & 11.86 \\
\hline Tangibility (TAN) & 18,084 & 0.26 & 0.15 & -0.21 & 1.00 \\
\hline Investments (INV) & 18,084 & 0.21 & 3.95 & -1.00 & 287.97 \\
\hline Cash Flow (CFLOW) & 18,084 & 0.04 & 0.14 & -6.63 & 3.09 \\
\hline Operating Profit & 18,085 & 281000000 & 1420000000 & -16800000000 & 54100000000 \\
\hline Market to Book (MTB) & 16,694 & 0.85 & 0.92 & 0.01 & 21.19 \\
\hline Lag Investment (lag INV) & 18,084 & 0.21 & 3.95 & -1.00 & 287.97 \\
\hline Lag Leverage (lag LEV) & 18,084 & 1.15 & 11.32 & 0.00 & 753.23 \\
\hline $\begin{array}{l}\text { Lag Return on Assets } \\
\text { (lag ROA) }\end{array}$ & 18,084 & 0.04 & 0.14 & -6.65 & 1.47 \\
\hline $\begin{array}{l}\text { Lag Unused Debt Capacity (lag } \\
\text { UDC) }\end{array}$ & 18,104 & -0.83 & 11.31 & -752.97 & 0.62 \\
\hline Lag Firm Size (lag FS) & 18,084 & 9.39 & 0.51 & 7.03 & 11.86 \\
\hline $\begin{array}{l}\text { Lag Market to Book } \\
\text { (lag MTB) }\end{array}$ & 16,694 & 0.85 & 0.92 & 0.01 & 21.19 \\
\hline Lag Tangibility (lag TAN) & 18,084 & 0.26 & 0.15 & -0.21 & 1.00 \\
\hline Lag Cash (lag Cash) & 18,084 & 0.18 & 0.14 & 0.00 & 1.00 \\
\hline Lag Cash Flow(lag CFLOW) & 18,084 & 0.04 & 0.14 & -6.63 & 3.09 \\
\hline Economic Crisis & 18,425 & 0.04 & 0.20 & 0.00 & 1.00 \\
\hline Residuals & 16,528 & -0.63 & 3.27 & -137.07 & 1.30 \\
\hline Small or Large firms & 18,085 & 0.19 & 0.40 & 0.00 & 1.00 \\
\hline
\end{tabular}

Table 3: Pearson Pairwise Correlation Matrix

\begin{tabular}{|l|r|r|r|r|r|r|r|}
\hline & LEV & UDC & ROA & CASH & FS & TAN & CFLOW \\
\hline Leverage(LEV) & 1 & & & & & & \\
\hline Return on Assets & -0.121 & 0.120 & 1.000 & & & & \\
\hline Cash Ratio & -0.011 & 0.006 & 0.195 & 1.000 & & & \\
\hline Firm Size ln(FS) & -0.129 & 0.129 & 0.130 & -0.144 & 1.000 & & \\
\hline Tangibility & -0.003 & 0.008 & -0.116 & -0.428 & 0.108 & 1.000 & \\
\hline Cash Flow(CFLOW) & 0.130 & -0.131 & 0.945 & 0.194 & 0.079 & -0.120 & 1.000 \\
\hline Market to Book (MTB) & -0.059 & 0.062 & -0.112 & -0.201 & 0.401 & 0.223 & -0.121 \\
\hline Lag Investment & -0.006 & 0.006 & 0.018 & -0.017 & 0.052 & -0.011 & 0.015 \\
\hline lag Leverage & 0.817 & -0.817 & -0.089 & -0.017 & -0.115 & -0.005 & 0.115 \\
\hline lag Unused Debt Capacity & -0.817 & 0.817 & 0.088 & 0.014 & 0.115 & 0.009 & -0.116 \\
\hline lag Market to Book & -0.051 & 0.055 & -0.116 & -0.170 & 0.352 & 0.226 & -0.124 \\
\hline lag Tangibility & -0.004 & 0.007 & -0.059 & -0.325 & 0.119 & 0.814 & -0.064 \\
\hline lag Cash Flow & 0.131 & -0.132 & 0.221 & 0.147 & 0.081 & -0.094 & 0.271 \\
\hline lag Cash & -0.013 & 0.010 & 0.167 & 0.607 & -0.114 & -0.353 & 0.163 \\
\hline Investment & 0.056 & -0.056 & -0.083 & -0.012 & -0.092 & -0.003 & -0.061 \\
\hline
\end{tabular}


Table 3: Pearson Pairwise Correlation Matrix (Cont.')

\begin{tabular}{|l|c|c|c|c|c|c|c|c|c|}
\hline & MTB & Lag INV & Lag LEV & Lag UDC & Lag MTB & Lag TAN & Lag CFLOW & lagCash & INV \\
\hline Market to Book & 1 & & & & & & & & \\
\hline Lag Investment & 0.031 & 1.000 & & & & & & & \\
\hline lag Leverage & -0.050 & 0.056 & 1.000 & & & & & & \\
\hline lag Market to Book & 0.743 & -0.030 & -0.059 & 0.062 & 1.000 & & & & \\
\hline lag Tangibility & 0.201 & -0.003 & -0.003 & 0.008 & 0.223 & 1.000 & & & \\
\hline lag Cash Flow & -0.097 & -0.061 & 0.130 & -0.131 & -0.121 & -0.120 & 1.000 & & \\
\hline lag Cash & -0.170 & -0.012 & -0.011 & 0.006 & -0.201 & -0.428 & 0.194 & 1.000 & \\
\hline Investment & -0.030 & -0.005 & 0.029 & -0.029 & -0.026 & -0.012 & -0.009 & -0.008 & 1.000 \\
\hline
\end{tabular}

\section{Regression Results and Discussion}

Determination of Firms' Target Leverage Level and Financial Flexibility

We measure firms target leverage and financial flexibility by using the following regression model:

$\operatorname{Lev}_{\mathrm{i}, t=\beta_{0}+} \beta_{1} \mathrm{LEV}_{\mathrm{i},-1-1}+\beta_{2} \mathrm{MTB}_{\mathrm{i}, t+} \quad \beta_{3} \mathrm{FS}_{\mathrm{i}, t}+\beta_{4} \mathrm{TAN}_{\mathrm{i}, t+}$

$\beta_{5} \mathrm{ROA}_{\mathrm{i}, \mathrm{t}}+\delta_{\mathrm{i}}+\eta_{\mathrm{t}}+\mu_{\mathrm{i}}$
Table 4 shows the target leverage level of the firms through the relationship between the current and following year leverage levels. The model (2) determines the impact of financial components on firms' leverage behavior. The result indicated the coefficient between leverage and lagged leverage is $\beta=0.686$, $p$-value $<0.001$, which implies that with the current status of leverage, firms can adopt $68.6 \%$ more debts. Also, the results indicate that with the changes of $1 \%$ lag Leverage, the leverage will be increased by $0.686 \%$, which notify that firms have Unused Debt Capacity (UDC).

Table 4: The relationship between leverage and expected leverage

\begin{tabular}{|c|c|c|c|}
\hline & \multicolumn{3}{|c|}{ Dependent Variable: Leverage } \\
\hline & LEV & & \\
\hline \multirow[t]{2}{*}{ Independent Variables: lagLEV } & $0.686^{* * *}$ & & \\
\hline & -139.25 & & \\
\hline \multirow[t]{2}{*}{ Market to Book Ratio (MTB) } & -0.000512 & & \\
\hline & $(-0.02)$ & & \\
\hline \multirow[t]{2}{*}{ Firm Size $\ln (\mathrm{FS})$} & $-0.525^{* * *}$ & & \\
\hline & $(-9.55)$ & & \\
\hline \multirow[t]{2}{*}{ Tangibility (TAN) } & -0.206 & & \\
\hline & $(-1.29)$ & & \\
\hline \multirow[t]{2}{*}{ Return on Assets (ROA) } & $-1.349^{* * *}$ & & \\
\hline & $(-7.43)$ & & \\
\hline \multirow[t]{2}{*}{ _cons } & $5.309^{* * * *}$ & & \\
\hline & -10.6 & & \\
\hline $\mathrm{N}$ & 16528 & & \\
\hline Year Effect & Yes & & \\
\hline Industry Effect & Yes & & \\
\hline $\mathrm{t}$ statistics in parentheses & $=" * p<0.05$ & $* * \mathrm{p}<0.01$ & $* * * p<0.001 "$ \\
\hline \multicolumn{4}{|c|}{$\begin{array}{l}\text { Notes: Leverage is the ratio of the book value of total debts divided by total assets. Market to Book ratio is calculated } \\
\text { as (Book Value of Total Assets-Book Value of Equity +Market Value of Equity) scaled by total assets. Firm Size is the } \\
\text { natural logarithm of total assets. Assets tangibility is calculated as total fixed assets divided by total assets. Return on } \\
\text { Assets is the net operating income to total assets. Lag lev is the one year lag of leverage. Return on Assets is the net } \\
\text { operating income divided by total assets. }\end{array}$} \\
\hline
\end{tabular}

\section{Financial Flexibility and Investment Ability}

This study utilizes the following econometric model to examine the relationship between financial flexibility and investment ability:
$\operatorname{Inv}_{i, t}=\beta_{0}+\beta_{1} \operatorname{INV}_{i, t-1}+\beta_{2} C_{F L O W}, t+\beta_{3} R A_{i, t}+\beta_{4} F_{i, t}+\beta_{5}\left(F_{i, t}\right.$

$\left.{ }^{*} \mathrm{CFLOW}_{\mathrm{i}, \mathrm{t}-1}\right)+\delta_{\mathrm{i}}+\eta_{\mathrm{t}}+\mu_{\mathrm{i}, \mathrm{t}}$

The association between current year investment and following year possible investment is presented in Table 5 considering cases with financial flexibility and with/without financial flexibility. The multiple regression 
results show the coefficient of previous year investment (lagINV) and investments ability is $\beta=-0.0253$ and $p$ value $<0.001$, which indicates that with the changes of $1 \%$ of previous year investments (LagINV), the investment ability decreases by $0.0782 \%$ for inflexible firms and $0.0253 \%$ for flexible firms. While considering financial flexibility with the interaction of cash flow sensitivity shows that their $1 \%$ changes might increase $0.0175 \%$ of investment ability.

Thus, financial flexibility with cash flow sensitivity has the power to invest more in the future, and this result conforms to our hypothesis $\mathrm{H}_{1}$ : Financial flexible firms are positively associated with future investment expenditure. Also, the interaction between financial flexibility with cash flow sensitivity on firms' investment presented in column three that firms with financial flexibility and cash flow sensitivity can increase investment by $0.0175 \%$. The results indicate a significant positive relationship with the investment of the firms, meaning that flexible firms have a strong ability to respond to potential investment opportunities.

Table 5: Relationship between investment and investment ability

\begin{tabular}{|c|c|c|c|}
\hline & (1) & (2) & (3) \\
\hline \multirow{2}{*}{ Dependent variable } & Investment & Investment & Investment \\
\hline & With Flexibility & Without Flexibility & Full Sample \\
\hline \multicolumn{4}{|l|}{ Independent Variables: } \\
\hline \multirow[t]{2}{*}{ lagINV } & $-0.0253^{* * *}$ & $-0.0782^{* * *}$ & $-0.0532^{* * *}$ \\
\hline & $(-4.06)$ & $(-3.51)$ & $(-6.71)$ \\
\hline \multirow[t]{2}{*}{ Financial Flexibility * Lag CFLOW } & 0.664 & $0.0175^{* * *}$ & $0.0175^{* * *}$ \\
\hline & $(0.40)$ & $(4.20)$ & $(6.60)$ \\
\hline \multirow[t]{2}{*}{ Financial Flexibility } & $-0.707^{*}$ & -0.000602 & -0.00529 \\
\hline & $(-2.30)$ & $(-0.06)$ & $(-0.92)$ \\
\hline \multirow[t]{2}{*}{ Cash Flow (CFLOW) } & $6.542^{*}$ & 0.232 & 1.722 \\
\hline & $(2.34)$ & $(0.10)$ & (1.35) \\
\hline \multirow[t]{2}{*}{ lagCFLOW } & -0.675 & $1.502^{* *}$ & $0.597^{*}$ \\
\hline & $(-1.05)$ & $(3.06)$ & $(2.35)$ \\
\hline \multirow[t]{2}{*}{ Return on Assets (ROA) } & $-7.007^{*}$ & -1.347 & $-2.975^{*}$ \\
\hline & $(-2.50)$ & $(-0.60)$ & $(-2.31)$ \\
\hline \multirow[t]{2}{*}{ _cons } & $0.344^{* * *}$ & $0.348^{* * *}$ & $0.233^{* * *}$ \\
\hline & $(4.07)$ & $(3.91)$ & $(6.83)$ \\
\hline $\mathrm{N}$ & 11901 & 6004 & 17905 \\
\hline Year Effect & Yes & Yes & Yes \\
\hline Industry Effect & Yes & Yes & Yes \\
\hline $\mathrm{t}$ statistics in parentheses & $=" * p<0.05$ & ${ }^{* *} \mathrm{p}<0.01$ & $* * * \mathrm{p}<0.001^{\prime \prime}$ \\
\hline \multicolumn{4}{|c|}{$\begin{array}{l}\text { Notes: Financial Flexibility }=\text { Unused debt capacity, it is the borrowing capacity which is unused UDC }=(\text { TDC- } \\
\text { DC).Debt Capacity is computed as }\left(\left(0.715^{*} \text { receivables }\right)+\left(.547^{*} \text { inventory }\right)+\left(.535^{*} \mathrm{PPE}\right)\right) \text { divided by total assets } \\
\text { (Estwick, 2016), following related literature (Almeida and Campello, 2007;Almeida et al., 2014). To get UDC, this } \\
\text { study deducts the leverage ratio from Debt Capacity (DC) (Estwick, 2016). Investment is the ratio of the net changes } \\
\text { in property, plant, and equipment with the addition of the maintenance costs to the total assets. Cash flow is the net } \\
\text { operating income plus depreciation and amortization scaled by total assets. }\end{array}$} \\
\hline
\end{tabular}

Among the control variables, cash flows show a significant positive relationship with investment ability, with the firms having financial flexibility. It indicates that a $1 \%$ increase in cash flows in the flexible firms the capacity to investment increases by $6.54 \%$. In contrast, cash flow sensitivity and investment are positively related to the ability to invest in inflexible firms. Return on investments shows a weak significant negative relationship on investment for flexible firms, while no significant association with non-flexible firms. This may be due to reason than accounting income is not merely effective on investment ability due to accruals, where cash flows show a substantial impact on investment ability.

\section{Measuring Relationships between Financial Flexibility and Expected Investments}

To measure the relationships between financial flexibility and expected investments, the following econometrics model has been used:

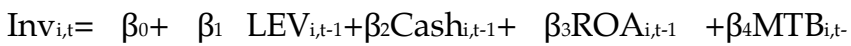

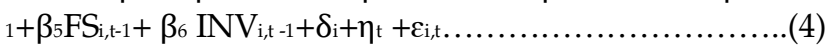


Table 6 shows that the coefficient between previous year investments (lag INV) and expected investments with flexibility is $\beta=-0.0432$ and $p$-value $<0.001$, with infers that $1 \%$ increase in previous year investments, the expected investment is reduced by $0.0432 \%$ in flexible firms, while $0.198 \%$ decreased for inflexible firms. It indicates that $(19.8 \%-4.32 \%)=15 \%$ investment can stimulate by flexible firms. It supports our hypothesis

$\mathrm{H}_{2}$ : Financial flexibility can reduce the level of suboptimal investments.
Alongside, considering cash flow sensitivity, the negative indicator turns to positive, meaning that with the financial flexibility, if the firms have free cash flow, then the investment ability expedite. However, the previous year's leverage does not affect the firm's investments, although they show an insignificant positive relationship with investments. It also indicates that last year leverage increases the free cash flow and can improve investment ability.

Table 6: Regression results for expected investments and financial flexibility

\begin{tabular}{|c|c|c|c|}
\hline & $(1)$ & $(2)$ & (3) \\
\hline & Expected Investment & Expected Investment & Expected Investment \\
\hline Variables: & Full Sample & With Flexibility & Without Flexibility \\
\hline \multirow[t]{2}{*}{ lagINV } & $-0.0725^{* * *}$ & $-0.0432^{* * *}$ & $-0.198^{*}$ \\
\hline & $(-8.74)$ & $(-5.46)$ & $(-2.34)$ \\
\hline \multirow[t]{2}{*}{ lagLEV } & 0.00214 & 0.166 & 0.00190 \\
\hline & $(0.30)$ & $(1.77)$ & $(0.18)$ \\
\hline \multirow[t]{2}{*}{ lagCash } & -0.251 & 0.326 & $-1.151^{*}$ \\
\hline & $(-1.03)$ & $(1.22)$ & $(-2.07)$ \\
\hline \multirow[t]{2}{*}{ lagROA } & 0.228 & -0.646 & $1.074^{* *}$ \\
\hline & $(1.03)$ & $(-1.87)$ & $(2.64)$ \\
\hline \multirow[t]{2}{*}{ lagMTB } & -0.0299 & -0.0444 & -0.0348 \\
\hline & $(-0.71)$ & $(-1.11)$ & $(-0.26)$ \\
\hline \multirow[t]{2}{*}{ lagFS } & $-0.822^{* * *}$ & $-0.732^{* * *}$ & $-1.049^{* * * *}$ \\
\hline & $(-9.38)$ & $(-7.78)$ & $(-4.44)$ \\
\hline \multirow[t]{2}{*}{ _cons } & $7.978^{* * *}$ & $7.073^{* * *}$ & $10.18^{* * *}$ \\
\hline & $(9.70)$ & $(7.94)$ & $(4.66)$ \\
\hline $\mathrm{N}$ & 16523 & 10957 & 5566 \\
\hline Year Effect & Yes & Yes & Yes \\
\hline Industry Effect & Yes & Yes & Yes \\
\hline $\mathrm{t}$ statistics in parentheses & $=" * p<0.05$ & ${ }^{* *} p<0.01$ & ${ }^{* * *} \mathrm{p}<0.001 "$ \\
\hline \multicolumn{4}{|c|}{$\begin{array}{l}\text { Notes: Financial Flexibility }=\text { Unused debt capacity, it is the borrowing capacity which is unused UDC=(TDC-DC).Debt } \\
\left.\text { Capacity is computed as }\left(0.715^{*} \text { receivables }\right)+\left(.547^{*} \text { inventory }\right)+\left(.535^{*} P P E\right)\right) \text { divided by total assets (e.g.,Estwick, 2016), } \\
\text { following related literature (Almeida and Campello, 2007;Almeida et al., 2014). To get UDC, this study deducts the leverage } \\
\text { ratio from Debt Capacity (DC) (e.g.,Estwick, 2016). Crisis is a dummy variable, the value of 2008-2009=1 otherwise 0. Lag } \\
\text { variables are the one-year lag value of a particular variable. }\end{array}$} \\
\hline
\end{tabular}

Among the control variable, previous year cash ratio to total assets, return on investments, and firms' growth ratio seem not to affect expected investments apart in the prior year cash ratio that shows the significant negative relationship for firms without financial flexibility. And return on assets shows a substantial positive relationship with firm's expected investment for the firms without flexibility.

\section{Financial Flexibility and Investment Efficiency}

In Table-6, we have evidenced that flexible financial firms' are capable of increasing the overall investment levels compared to inflexible firms due to the easy access to the external funds and relieving pressures from debt holders and stockholders. In line with increased investment,
Table7 evidence that financial flexibility can expedite investment efficiency. Following the approach of Richardson (2006), this research predicts the expected investment shown in Table- 6 and calculates the residual of the regression model of expected investments. The residuals are considered as under or over investment and taking the absolute value of residuals. We measure investment efficiency following (Cherkasova and Kuzmin, 2018; Richardson, 2006).

The financial flexibility and investment efficiency is measured by using the following regression model:

$\mathrm{IE}_{\mathrm{i}, \mathrm{t}}=\boldsymbol{\beta}_{\mathbf{0}}+\boldsymbol{\beta}_{1} \mathrm{FF}_{\mathrm{i}, \mathrm{t}}+\boldsymbol{\beta}_{2} \mathrm{FS}_{\mathrm{i}, \mathrm{t}-1}+\boldsymbol{\beta}_{3} \mathrm{TAN}_{\mathrm{i}, \mathrm{t}-1}+\boldsymbol{\beta}_{4}$ ROA $_{\mathrm{i}, \mathrm{t}-1}+\boldsymbol{\delta}_{\mathrm{i}}+\boldsymbol{\eta}_{\mathrm{t}}+\boldsymbol{\mu}_{\mathrm{i}, \mathrm{t}}$ 
The association between financial flexibility and investment efficiency is illustrated in Table7. We see the relationship based on the whole sample and then based on the crisis period as well as firm characteristics (large or small). The table shows that financial flexibility measured by unused debt capacity increases investment efficiency at different magnitude. The coefficient of financial flexibility and investment efficiency for all sample is $\beta=0.432$ and $p$-value $<0.001$, in the crisis period $\beta=0.433$ and $p$-value $=0.001$, for large firms $\beta=0.505 p$ value $<0.001$, and small firms is $\beta=0.371$ and $p$ - value $<0.001$. The results indicate that $1 \%$ increases in financial flexibility the investment efficiency increased by $0.432 \%$ for all firms', $0.433 \%$ during the crisis period, $0.505 \%$ for large firms', and $0.371 \%$ for small firms' respectively. These findings support our hypothesis that $\mathrm{H}_{3}$ : Financial Flexibility and investment efficiency is positively related in economic crisis and negates $\mathrm{H}_{4}$ : Financial flexibility has the same impact regardless of firms' size as larger firms show more investment effectiveness than their counterpart.

Table 7: Relationship between financial flexibility and investment efficiency

\begin{tabular}{|c|c|c|c|c|}
\hline & (1) & $(2)$ & (3) & $(4)$ \\
\hline & $\begin{array}{l}\text { Investment } \\
\text { Efficiency }\end{array}$ & $\begin{array}{l}\text { Investment } \\
\text { Efficiency }\end{array}$ & $\begin{array}{l}\text { Investment } \\
\text { Efficiency }\end{array}$ & $\begin{array}{l}\text { Investment } \\
\text { Efficiency }\end{array}$ \\
\hline Variables: & All Sample & Crisis & Large Firms' & Small Firms' \\
\hline \multirow[t]{2}{*}{ Financial Flexibility } & $0.432 * * *$ & $0.433^{* * *}$ & $0.505^{* * *}$ & $0.371^{* * *}$ \\
\hline & $(86.81)$ & $(86.88)$ & $(20.13)$ & $(65.12)$ \\
\hline \multirow[t]{2}{*}{ Financial Crisis *Financial Flexibility } & & $-0.110 * * *$ & -0.0164 & $-0.103 * *$ \\
\hline & & $(-3.72)$ & $(-0.08)$ & $(-3.24)$ \\
\hline \multirow[t]{2}{*}{ lagTAN } & $0.656 * * *$ & $0.649 * * *$ & $0.836 * * *$ & $0.902 * * *$ \\
\hline & (3.66) & (3.62) & $(8.07)$ & $(4.22)$ \\
\hline \multirow[t]{2}{*}{$\operatorname{lagROA}$} & $0.978 * * *$ & $0.973^{* * *}$ & $1.527^{* * *}$ & $0.976^{* * *}$ \\
\hline & $(6.61)$ & $(6.57)$ & $(8.94)$ & $(5.98)$ \\
\hline \multirow[t]{2}{*}{ 1.crisis } & & 0.0628 & -0.0144 & 0.0940 \\
\hline & & $(0.78)$ & $(-0.24)$ & $(0.98)$ \\
\hline \multirow[t]{2}{*}{ lagFS } & $1.314 * * *$ & $1.321 * * *$ & $0.736 * * *$ & $1.521 * * *$ \\
\hline & $(25.01)$ & $(25.10)$ & $(24.77)$ & $(20.62)$ \\
\hline \multirow[t]{2}{*}{ cons } & $-12.90 * * *$ & $-12.97 * * *$ & $-7.483 * * *$ & $-14.85 * * *$ \\
\hline & $(-25.87)$ & $(-25.94)$ & $(-24.49)$ & $(-21.69)$ \\
\hline $\mathrm{N}$ & 16528 & 16528 & 3180 & 13348 \\
\hline Year Effect & Yes & Yes & Yes & Yes \\
\hline Industry Effect & Yes & Yes & Yes & Yes \\
\hline t statistics in parentheses & $=" * p<0.05$ & $* * \mathrm{p}<0.01$ & $* * * \mathrm{p}<0.001 "$ & \\
\hline \multicolumn{5}{|c|}{$\begin{array}{l}\text { Notes: Financial Flexibility = Unused debt capacity, it is the borrowing capacity which is unused UDC }=(T D C- \\
\text { DC).Debt Capacity is computed as }\left(\left(0.715^{*} \text { receivables }\right)+(.547 * \text { inventory })+(.535 * P P E)\right) \text { divided by total assets } \\
\text { (e.g.,Estwick, 2016), following related literature }(\text { Almeida and Campello, 2007; Almeida et al., 2014). To get UDC, } \\
\text { this study deducts the leverage ratio from Debt Capacity }(D C)(\text { Estwick, 2016). Crisis is a dummy variable, the value } \\
\text { of } 2008-2009=1 \text { otherwise 0. Lag variables are the one-year lag value of the particular variable. }\end{array}$} \\
\hline
\end{tabular}

Among the control variable following year return on investments, total assets, and property, plant and equipment increase the level of investment as well as the investment efficiency, which are consistent with the previous research (Cherkasova and Kuzmin, 2018). During the crisis, investment efficiency is not relevant for firms as borrowing becomes impossible, and investment becomes stagnant for inflexible firms'. However, the interaction of financial crisis and financial flexibility seems to have significantly negative to firms' investment efficiency. The possible explanation of this, large firms affected seriously by crisis compared to their counterparts entailing cut of investment and reduction of stuff that altogether have minor effects for flexible firms' operation.

\section{Robustness CHECK}

To testify the robustness of the above test result, we consider cash holdings as an alternative proxy of financial flexibility using the GMM estimation model and controlling the year and industry effects shown in Table8. Consistent with the previous result, we find that 
financial flexibility enhances investment efficiency showing the coefficient of financial flexibility and investment efficiency is $\beta=0.945$ and $p$-value $<0.001$. The results robust our findings that financial flexibility

Table 8: The regression results with robust standard errors instigates investment efficiency. The outcome of the test is consistent with the methodology used in this paper, and therefore, the conclusions remain unchanged.

Dependent Variable: Investment Efficiency (IE)

IE

IE

\begin{tabular}{|c|c|c|c|}
\hline \multicolumn{2}{|l|}{ Independent Variables: } & \multicolumn{2}{|l|}{ Control Variables : } \\
\hline Financial Flexibility & $\begin{array}{l}0.945^{* * *} \\
(5.07)\end{array}$ & Long Term Debts (LTD) & $\begin{array}{l}-0.744 * * * \\
(-42.49)\end{array}$ \\
\hline LagFF & $\begin{array}{l}-0.514 * * \\
(-3.10)\end{array}$ & Short Term Debts (STD) & $\begin{array}{l}-0.261 * * * \\
(-24.99)\end{array}$ \\
\hline \multicolumn{4}{|l|}{ Control Variables: } \\
\hline Asset Tansibility & $\begin{array}{l}0.483^{*} \\
(2.20)\end{array}$ & Cash Flow (CFLOW) & $\begin{array}{l}4.021 * * * \\
(5.12)\end{array}$ \\
\hline Firm Size ln. (FS) & $\begin{array}{l}0.957 * * * \\
(14.75)\end{array}$ & Book to Market (MTB) & $\begin{array}{l}-0.0353 \\
(-1.25)\end{array}$ \\
\hline Return on Assets (ROA) & $\begin{array}{l}-3.212 * * * \\
(-4.03)\end{array}$ & Z-Score & $\begin{array}{l}-0.0123 \\
(-1.48)\end{array}$ \\
\hline _cons & $-9.443 * * *$ & & \\
\hline $\mathrm{N}$ & $\begin{array}{l}(-14.97) \\
16528\end{array}$ & & \\
\hline Industry Fixed Effects & Yes & & Yes \\
\hline $\begin{array}{l}\text { Year Fixed Effects } \\
\text { t statistics in parentheses }=" * p<0.05^{* *}\end{array}$ & $\begin{array}{l}\text { Yes } \\
\mathrm{p}<0.01 * * *\end{array}$ & $0.001 "$ & Yes \\
\hline
\end{tabular}

\section{CONCLUSION}

This research is the nexus study of corporate finance, which addresses the less attended area of research on financial flexibility and investment effectiveness in the emerging economy. The comprehension of financial flexibility and investment effectiveness in emerging economies is essential due to its uniqueness of financing, which mainly depends on high costs banks or financial institutions borrowings. Emerging economies stimulate new investment prospects and instigate managers to search for tools to exacerbate the flexibility to fund the development and expansion of the business operation. Also, emerging economies suffer from a high level of the agency problem, and managers are overexposed to investment opportunities with excess flexibility. It is vital to address the financial flexibility and investment effectiveness to reduce the underinvestment or overinvestment in the emerging economies

This research examines 2034 manufacturing companies composed of nine different industries of 18 years of unbalanced data gathered from the Chinese Stock Market database CSMAR. We consider a total of 18425 unbalanced observations from 2000-2017. This study set out to investigate four research questions: What is the association between current leverage and future leverage? Second, what is the relationship between current investment and future expected investments and leverage? Third, how financial flexibility reduces suboptimal investments? Finally, does financial flexibility instigate investment efficiency in the emerging economy?

Our results support the following findings: First, financially flexible firms able to generate additional power to borrow external finance by showing a significant positive relationship with current leverage and expected leverage. They are indicating that the firms possess the unused debt capacity (a proxy of financial flexibility). Secondly, in the conformity of hypothesis 2 , we find that financial flexible firms can reduce the suboptimal investment by increasing investments compared to the inflexible firms. Thirdly, we find our support for our hypothesis that financial flexibility increases investment efficiency. Finally, this research negates that financial flexibility has a similar impact on investment efficiency, 
whether they are large or small in total assets. It implies that large firms make more efficient investment decisions than smaller firms.

Overall, the outcome of this research offers several conceptions for researchers and managers. The results suggest that financial flexibility can lead to additional borrowing capacity, which can be used to fund profitable projects as well as continuing business operations during bad times, especially when external financing is challenging. Besides, financial flexibility can be used to exploit lucrative projects and reduce underinvestment or overinvestment, which entails investment effectiveness.

\section{RESEARCH IMPLICATIONS}

This study has several policy implications as well as managerial implications. The policy implications include corporate cash policy and debt policy, as this study evidence that only $18 \%$ of cash to total assets are held by the business while the standard deviation is 0.14 . The finding indicates that the cash holding among companies varies and provides a high variance between mean and maximum cash holdings. Policymakers should have a devise cash policy so that a firm can react positively during the crisis like financial difficulty during pandemic coronavirus as well as the financial crisis and maintain an effective investment policy.

Besides, policymakers need to work on the debt policy, as most of the companies overused the debt $(-83 \%)$, which indicates the worsening of default risks due to using interest-bearing funds that may put pressure on investment efficiency. Moreover, the range of unused debt capacity is (-752.94 to 0.62$)$, which is also alarming for the firms and call for further boosting company management with skills executives and directors, and minimizing the deviation of UDC may produce better investment efficiency.

Firms are heterogeneous in emerging markets, and so do countries in the emerging economy. However, better corporate governance and the freedom to disclose independent director's opinions on important board decisions as well as two tiers corporate governance systems in the system might reduce information asymmetry and instigate investment efficiency in the emerging economy.

Thus, the outcome of the research might be equally important for the emerging as well as advanced economy despite the research conducted in the emerging Chinese market. The study is useful for policymakers and managers to design their cash and debt levels and avoid the hurdle of obtaining external finance or accelerating their flexibility to raise money from an external source. Moreover, we considered manufacturing industries for the resemblances of rules and regulations applied to the industries. Other sectors like Oil \& Gas, Mining, Bank, and
Insurance are not considered due to the self-regulation of the segments, as well as other countries, and the environment are not considered due to the heterogeneity of countries and the environment. The study of financial flexibility for financial firms may be an excellent initiative for future projects.

\section{REFERENCES}

Al-Najjar, B. \& Clark, E. 2017. Corporate Governance And Cash Holdings In Mena: Evidence From Internal And External Governance Practices. Research In International Business And Finance, 39, 1-12.

Almeida, H. \& Campello, M. 2007. Financial Constraints, Asset Tangibility, And Corporate Investment. The Review Of Financial Studies, 20, 1429-1460.

Almeida, H., Campello, M., Cunha, I. \& Weisbach, M. S. 2014. Corporate Liquidity Management: A Conceptual Framework And Survey. Annu. Rev. Financ. Econ., 6, 135162.

Arellano, M. \& Bond, S. 1991. Some Tests Of Specification For Panel Data: Monte Carlo Evidence And An Application To Employment Equations. The Review Of Economic Studies, 58, 277-297.

Arslan-Ayaydin, Ö., Florackis, C. \& Ozkan, A. 2014. Financial Flexibility, Corporate Investment And Performance: Evidence From Financial Crises. Review Of Quantitative Finance And Accounting, 42, 211-250.

Bates, T. W., Kahle, K. M. \& Stulz, R. M. 2009. Why Do Us Firms Hold So Much More Cash Than They Used To? The Journal Of Finance, 64, 1985-2021.

Bolton, P., Wang, N. \& Yang, J. 2019. Investment Under Uncertainty With Financial Constraints. Journal Of Economic Theory, 184, 104912.

Bonaimé, A. A., Hankins, K. W. \& Harford, J. 2013. Financial Flexibility, Risk Management, And Payout Choice. The Review Of Financial Studies, 27, 1074-1101.

Bryman, A. \& Cramer, D. 1997. Quantitative Data Analysis With Spss For Windows: A Guide For Social Scientists, Routledge.

Byoun, S. 2007. Financial Flexibility, Leverage, And Firm Size. Waco, Tx. January, 3.

Cherkasova, V. \& Kuzmin, E. 2018. Financial Flexibility As An Investment Efficiency Factor In Asian Companies. Gadjah Mada International Journal Of Business, 20, 137.

Cherkasova, V. \& Zakharova, E. 2016. Suboptimal Investments And M\&A Deals In Emerging Capital Markets. Ekonomski Anali/Economic Annals, 61.

De Jong, A., Verbeek, M. \& Verwijmeren, P. 2012. Does Financial Flexibility Reduce Investment Distortions? Journal Of Financial Research, 35, 243-259.

Deangelo, H. \& Deangelo, L. 2007. Capital Structure, Payout Policy, And Financial Flexibility. Marshall School Of Business Working Paper No. Fbe, 02-06.

Denis, D. J. \& Mckeon, S. B. 2009. Financial Flexibility And Capital Structure Policy: Evidence From Pro-Active Leverage Increases. Unpublished Working Paper, Purdue University. 
Denis, D. J. \& Mckeon, S. B. 2012. Debt Financing And Financial Flexibility Evidence From Proactive Leverage Increases. The Review Of Financial Studies, 25, 1897-1929.

Estwick, S. 2016. Principal-Principal Agency And Financial Flexibility In Transition Economies. The Journal Of Business Inquiry, 15, 33-54.

Ferrando, A., Marchica, M. T. \& Mura, R. 2017. Financial Flexibility And Investment Ability Across The Euro Area And The Uk. European Financial Management, 23, 87-126.

Graham, J. R. \& Harvey, C. R. 2001. The Theory And Practice Of Corporate Finance: Evidence From The Field. Journal Of Financial Economics, 60, 187-243.

Han, D. \& Zhang, P. 2016. Monetary Policy, Financing Constraints And Investment Efficiency: Evidence From Listed Private Companies Of China. Nankai Business Review International, 7, 80-98.

Hasan, M. S., Rahman, R. A. \& Hossain, S. Z. 2014. Monitoring Family Performance: Family Ownership And Corporate Governance Structure In Bangladesh. Procedia-Social And Behavioral Sciences, 145, 103-109.

Islam, M. R., Wang ,Man., And Dewri,Leo Vashkor 2019. Financial Flexibility-A Synthesis Review Of The Literature. International Journal Of Accounting And Financial Reporting, 9 12.

Jensen, M. C. 1986. Agency Costs Of Free Cash Flow, Corporate Finance, And Takeovers. The American Economic Review, 76, 323-329.

Jensen, M. C. 1994. Self-Interest, Altruism, Incentives, And Agency Theory. Journal Of Applied Corporate Finance, 7, 4045 .

Jensen, M. C. \& Meckling, W. H. 1976. Theory Of The Firm: Managerial Behavior, Agency Costs And Ownership Structure. Journal Of Financial Economics, 3, 305-360.

La Rocca, M., La Rocca, T. \& Gerace, D. 2008. A Survey Of The Relation Between Capital Structure And Corporate Strategy. Australasian Accounting, Business And Finance Journal, 2, 1.

Li, K., Lu, L., Mittoo, U. R. \& Zhang, Z. 2015. Board Independence, Ownership Concentration And Corporate Performance-Chinese Evidence. International Review Of Financial Analysis, 41, 162-175.
Ma, C.-A. \& Jin, Y. 2016. What Drives The Relationship Between Financial Flexibility And Firm Performance: Investment Scale Or Investment Efficiency? Evidence From China. Emerging Markets Finance And Trade, 52, 2043-2055.

Marchica, M. T. \& Mura, R. 2010. Financial Flexibility, Investment Ability, And Firm Value: Evidence From Firms With Spare Debt Capacity. Financial Management, 39, 13391365.

Mittoo, U. R. \& Bancel, F. 2011. Financial Flexibility And The Impact Of The Global Financial Crisis. International Journal Of Managerial Finance.

Modigliani, F. \& Miller, M. H. 1963. Corporate Income Taxes And The Cost Of Capital: A Correction. The American Economic Review, 53, 433-443.

Myers, S. C. 1974. Interactions Of Corporate Financing And Investment Decisions-Implications For Capital Budgeting. The Journal Of Finance, 29, 1-25.

Myers, S. C. \& Majluf, N. S. 1984. Corporate Financing And Investment Decisions When Firms Have Information That Investors Do Not Have. Journal Of Financial Economics, 13, $187-221$

Nouri, M. \& Jafari, S. M. 2016. The Impact Of Financial Flexibility On Investment Efficiency (Over-Investment And UnderInvestment) With Respect To Managerial Ownership In The Firms Listed In Tehran Stock Exchange. Icp Business. Economics And Finance, 3, 18-22.

Oded, J. 2019. Payout Policy, Financial Flexibility, And Agency Costs Of Free Cash Flow. Financial Flexibility, And Agency Costs Of Free Cash Flow (January 29, 2019).

Richardson, S. 2006. Over-Investment Of Free Cash Flow. Review Of Accounting Studies, 11, 159-189.

Titman, S., Wei, K. J. \& Xie, F. 2009. Capital Investments And Stock Returns In Japan. International Review Of Finance, 9, 111-131.

Yung, K., Li, D. D. \& Jian, Y. 2015. The Value Of Corporate Financial Flexibility In Emerging Countries. Journal Of Multinational Financial Management, 32, 25-41.

$--0-$ 


\section{How to cite this article:}

Islam, M. R., Hossain, M. A., Uddin, M. S., \& Bahta, D. T. (2020). Does Financial Flexibility foster Investment Efficiency? Evidence from an Emerging Market. Asian Business Review, 10(2), 121-136. https://doi.org/10.18034/abr.v10i2.476 